\title{
CORRELATION BETWEEN INTEREST IN LEARNING AND MATHEMATICS LEARNING OUTCOMES TO FOURTH GRADE STUDENTS OF PUBLIC ELEMENTARY SCHOOLS IN PREMBUN SUB-DISTRICT IN ACADEMIC YEAR OF 2020/2021
}

\author{
Amanda Putri Nurjanah', Suhartono², Ratna Hidayah ${ }^{3}$ \\ Universitas Sebelas Maret \\ amandapnj@gmail.com
}

\section{Article History}

accepted 30/8/2021

approved 30/9/2021

published 30/10/2021

\begin{abstract}
The study aimed to: (1) determine the correlation between interest in learning and mathematics learning outcomes to fourth grade students of public elementary schools in Prembun Subdistrict in academic year of 2020/2021, (2) measure the contribution of interest in learning on mathematics learning outcomes to fourth grade students of public elementary schools in Prembun Sub-district in academic year of 2020/2021. The research was correlational quantitative method. Sampling method was with cluster random sampling technique with the help of SPSS application. The samples were 226 fourth grade students in eleven elementary schools throughout the Prembun Sub-district. Data collection techniques used questionnaires and tests. Data Analysis used simple correlation test and adjusted $R$ square with a significance level of 5\%. The results indicated that: (1) there is positive and significant correlation between interest in learning and mathematics learning outcomes to fourth grade students of public elementary schools in Prembun Sub-district with the value of $r$ count $(0.486)>r$ table (0.130), (2) interest in learning contributes $23.69 \%$ on mathematics learning outcomes. The results of this study are in accordance with existing theories and are also supported by relevant research.

Keywords: interest in learning, mathematics learning outcomes
\end{abstract}

\begin{abstract}
Abstrak
Penelitian ini bertujuan untuk: (1) menemukan ada tidaknya hubungan antara minat belajar dan hasil belajar matematika siswa kelas IV SDN se-Kecamatan Prembun tahun ajaran 2020/2021, (2) mengukur besarnya sumbangan minat belajar terhadap hasil belajar matematika siswa kelas IV SDN se-Kecamatan Prembun tahun ajaran 2020/2021. Penelitian ini merupakan penelitian kuantitatif dengan metode korelasi. Pengambilan sampel menggunakan cluster random sampling dengan SPSS. Jumlah sampel penelitian ini 226 siswa di sebelas SDN se-Kecamatan Prembun. Pengambilan data menggunakan angket dan tes. Analisis data yang digunakan yaitu uji korelasi sederhana dan sumbangan efektif dengan taraf signifikansi $5 \%$. Hasil penelitian ini menunjukkan: (1) adanya hubungan positif dan signifikan antara minat belajar dan hasil belajar matematika siswa kelas IV SDN se-Kecamatan Prembun dengan nilai $r$ hitung $(0,486)>r$ tabel $(0,130)$, (2) minat belajar memberikan sumbangan sebesar $23,69 \%$ terhadap hasil belajar matematika. Hasil penelitian ini telah sesuai dengan teori yang ada dan didukung dengan penelitian relevan.
\end{abstract}

Kata kunci: minat belajar, hasil belajar matematika. 


\section{PENDAHULUAN}

Matematika merupakan ilmu pengetahuan yang memiliki peranan penting dalam berbagai disiplin ilmu dan aspek kehidupan. Peran penting matematika diakui oleh Cockroft yang menyatakan bahwa akan sangat sulit atau tidaklah mungkin bagi seseorang untuk hidup pada abad ke-20 ini tanpa sedikitpun memanfaatkan matematika (Siagian, 2016: 60). Matematika merupakan salah satu muatan pelajaran yang dapat membantu dalam penyelesaian masalah praktis sehari-hari (Susanto, 2016: 185). Di Indonesia sendiri, tingkat penguasaan siswa terhadap mata pelajaran matematika masih tergolong rendah. Hal ini dapat dilihat dari hasil survei Programme for International Student Assessment (PISA) yang menunjukkan bahwa capaian matematika siswa Indonesia pada tahun 2018 menduduki peringkat ke-73 dari 79 negara partisipan (Hewi dan Shaleh, 2020: 35). Penguasaan matematika siswa dapat diukur melalui hasil belajar yang dicapai.

Hasil belajar merupakan hasil pencapaian siswa dalam mengerjakan tugas atau kegiatan pembelajaran melalui penugasan pengetahuan atau keterampilan mata pelajaran di sekolah yang biasanya ditunjukkan dengan nilai tes atau angka yang diberikan guru. Menurut Nisa' (2018: 21) tinggi rendahnya hasil belajar siswa dapat dipengaruhi oleh beberapa faktor, yaitu faktor internal dan faktor eksternal. Faktor internal merupakan faktor yang berasal dari dalam diri peserta didik, misalnya minat, kecerdasan, sikap, ketekunan dan kesehatan. Sedangkan faktor eksternal merupakan faktor yang berasal dari luar diri peserta didik yaitu keluarga, sekolah dan masyarakat. Dari beberapa faktor tersebut, salah satu faktor penting dalam diri siswa yang dapat memengaruhi keberhasilan belajar adalah minat (Slameto, 2010: 54).

Sejalan dengan hal tersebut, dikutip dari laman berita republika 2 Mei 2020, sebagai upaya untuk menegakkan Kegiatan Belajar Mengajar (KBM) di tengah Pandemi Covid-19, Kemendikbud telah mengatur kebijakan melalui Surat Edaran Nomor 4 tahun 2020 yang memuat empat hal strategi belajar di era pandemi, salah satu strategi kebijakan tersebut adalah pembelajaran yang disampaikan harus disesuaikan dengan memperhatikan kondisi minat belajar masing-masing anak. Dari hal tersebut, diketahui bahwa minat merupakan salah satu faktor penting yang memiliki keterkaitan dengan hasil belajar yang diperoleh anak.

Minat adalah rasa suka dan rasa ketertarikan pada suatu hal atau aktivitas tanpa ada yang menyuruh (Alwina, Syahrilfuddin, dan Fendrik, 2016: 3). Dengan adanya minat, siswa dapat lebih mudah dalam belajar dan memahami materi yang disampaikan oleh guru karena siswa memiliki rasa ketertarikan pada bahan ajar yang disampaikan, sehingga diharapkan minat belajar dapat mendorong nilai hasil belajar yang diperoleh siswa lebih baik. Minat belajar memiliki pengaruh terhadap hasil belajar siswa. Flowerday dan Shell (2015: 134), menyatakan bahwa "results indicate that situational interest had strong direct and indirect effects on learning, engagement, and attitude", maksudnya adalah minat situasional memiliki efek langsung dan tidak langsung yang kuat pada pembelajaran, keterlibatan, dan sikap. Selaras dengan hal tersebut, Dalyono menyebutkan bahwa minat belajar yang besar cenderung menghasilkan hasil belajar yang tinggi, sebaliknya jika minat belajar kurang maka akan menghasilkan hasil belajar yang rendah (Suciyati dan Mariamah, 2018: 143).

Berdasarkan hasil observasi yang dilakukan oleh peneliti pada 17 Desember 2020, data permasalahan yang diperoleh di salah satu sekolah dasar Kecamatan Prembun yakni SDN Sembirkadipaten diperoleh rata-rata hasil belajar Penilaian Tengah Semester siswa pada tiga mata pelajaran utama yaitu Bahasa Indonesia $(76,36)$, IPA $(80,07)$, dan Matematika $(75,10)$. Berdasarkan data tersebut, mata pelajaran matematika mendapatkan nilai rata-rata terendah yaitu 75,10 . dan IPA KD 3.5 dan 3.6 diperoleh 8\% nilai siswa di bawah KKM. Hal ini menunjukkan bahwa masih banyak siswa yang belum mencapai nilai ketuntasan yang telah ditetapkan. Informasi lain yang peneliti dapatkan adalah guru tidak dapat mengawasi pembelajaran siswa 
secara langsung, karena kegiatan belajar mengajar masih dalam kondisi pembelajaran jarak jauh/ online. Kurangnya rasa ketertarikan siswa dalam belajar matematika dilihat dari penyelesaian tugas yang terlambat dan keterlibatan siswa yang kurang saat pembelajaran. Kurangnya perhatian dan partisipasi siswa dalam memfokuskan pada materi yang disampaikan guru saat pembelajaran online, disebabkan guru tidak dapat menjelaskan materi secara langsung kepada siswa. Kurangnya kemauan siswa dalam belajar, disebabkan pembelajaran dilakukan secara online dan tidak dapat bertemu dengan guru dan teman-teman sekolah.

Berdasarkan permasalahan yang telah diuraikan di atas, peneliti memfokuskan permasalahan mengenai minat siswa dalam belajar dengan hasil belajar matematika. Peneliti tertarik untuk menguji hubungan yang ada pada kedua permasalahan tersebut. Memungkinkan bahwa minat belajar memiliki keterkaitan terhadap pencapaian hasil belajar siswa. Hal tersebut diperkuat dalam penelitian yang dilakukan oleh: pertama, Sughiarti (2016: 79) yang menerangkan bahwa terdapat hubungan yang positif dan signifikan antara minat belajar dengan hasil belajar siswa kelas V SD. Kedua, penelitian oleh Charli, Ariani, dan Asmara (2019: 52) yang menyimpulkan bahwa terdapat hubungan yang signifikan antara minat belajar dengan prestasi belajar fisika siswa Kelas XI. Ketiga, penelitian yang dilakukan oleh Anggriyani (2020: 174) yang menyatakan bahwa terdapat hubungan yang positif dan signifikan antara minat belajar dengan hasil belajar muatan IPS siswa kelas IV SD.

Dalam penelitian ini, memiliki keunikan yang tidak dapat ditemukan dalam penelitian yang lainnya, antara lain 1) penelitian ini dilakukan untuk mengetahui ada tidaknya hubungan antara minat belajar dan hasil belajar matematika siswa kelas IV SDN se-Kecamatan Prembun, 2) objek penelitian yang dipilih adalah siswa kelas IV SDN se-Kecamatan Prembun, 3) hasil belajar yang diteliti adalah mata pelajaran matematika siswa kelas IV, 4) indikator penelitian minat belajar yang digunakan peneliti berbeda dengan penelitian yang sudah ada sebelumnya, dan 5) mengingat situasi kondisi pembelajaran di era pandemi covid-19 yang dilaksanakan secara daring, minat belajar merupakan salah satu faktor penting yang memiliki hubungan dengan hasil belajar matematika siswa.

Berdasarkan penjelasan di atas, pemasalahan dalam penelitian ini adalah: (1) Apakah minat belajar siswa berkorelasi positif dengan hasil belajar matematika siswa kelas IV SDN se-Kecamatan Prembun tahun ajaran 2020/2021 ?; (2) Seberapa besar sumbangan minat belajar siswa terhadap hasil belajar matematika siswa kelas IV SDN se-Kecamatan Prembun tahun ajaran 2020/2021?.

Berdasarkan permasalahan di atas maka tujuan dari penelitian ini yaitu: (1) Menemukan ada tidaknya korelasi positif antara minat belajar dengan hasil belajar matematika siswa kelas IV SDN se-Kecamatan Prembun tahun ajaran 2020/2021; (2) Mengukur besarnya sumbangan minat belajar terhadap hasil belajar matematika siswa kelas IV SDN se-Kecamatan Prembun tahun ajaran 2020/2021.

\section{METODE}

Desain penelitian yang digunakan yaitu penelitian kuantitatif dengan metode penelitian korelasi sederhana. Analisis korelasi sederhana berfungsi untuk mengetahui hubungan antara dua variabel (Priyatno, 2012: 59). Analisis korelasi yang digunakan yaitu analisis korelasi Pearson Product Moment menggunakan bantuan aplikasi SPSS.

Populasi pada penelitian ini yaitu semua siswa kelas IV SDN di Kecamatan Prembun dengan jumlah 23 sekolah dasar. Pengambilan sampel dilakukan dengan teknik probability sampling jenis cluster random sampling. Jumlah sampel dalam penelitian ini yaitu 226 siswa di sebelas SDN di Kecamatan Prembun. Pengambilan sampel dilakukan secara random menggunakan aplikasi SPSS.

Teknik pengumpulan data yang digunakan dalam penelitian ini yaitu angket dan tes. Angket digunakan untuk mengumpulkan data penelitian pada variabel bebas yaitu 
minat belajar, sedangkan tes digunakan untuk mengumpulkan data penelitian pada variabel terikat yaitu hasil belajar matematika. Sebelum digunakan untuk penelitian, angket dan tes diuji validitas dan reliabilitasnya terlebih dahulu di dua SDN di Kecamatan Prembun.

Uji prasyarat data yang digunakan adalah uji normalitas dan uji linieritas. Uji hipotesis yang digunakan adalah uji korelasi sederhana yang digunakan untuk menguji ada atau tidaknya hubungan antara minat belajar dengan hasil belajar matematika dan sumbangan efektif yang digunakan untuk menemukan besarnya sumbangan variabel minat belajar terhadap variabel hasil belajar.

\section{HASIL DAN PEMBAHASAN}

Hubungan minat belajar dengan hasil belajar matematika siswa dicari menggunakan korelasi pearson product moment. Peneliti menggunakan bantuan aplikasi SPSS dalam menguji hipotesis penelitian. Hipotesis dalam penelitian ini yaitu terdapat korelasi positif dan signifikan antara minat belajar dengan hasil belajar matematika siswa kelas IV se-Kecamatan Prembun tahun ajaran 2020/2021. Adapun data minat belajar dan hasil belajar matematika siswa kelas IV SDN se-Kecamatan Prembun dapat dilihat pada tabel berikut.

Tabel 1. Data Minat Belajar

\begin{tabular}{ccc}
\hline \multirow{2}{*}{ No } & \multicolumn{2}{c}{ Minat Belajar } \\
\cline { 2 - 3 } & Interval & Frekuensi \\
\hline $\mathbf{1}$ & $56-59$ & 13 \\
\hline $\mathbf{2}$ & $60-63$ & 29 \\
\hline $\mathbf{3}$ & $64-67$ & 50 \\
\hline $\mathbf{4}$ & $68-71$ & 63 \\
\hline $\mathbf{5}$ & $72-75$ & 34 \\
\hline $\mathbf{6}$ & $76-79$ & 28 \\
\hline $\mathbf{7}$ & $80-84$ & 9 \\
\hline & Total & 226 \\
\hline
\end{tabular}

Tabel 2. Hasil Belajar Matematika

\begin{tabular}{ccc}
\hline \multirow{2}{*}{ No } & \multicolumn{2}{c}{ Hasil Belajar Matematika } \\
\cline { 2 - 3 } & Interval & Frekuensi \\
\hline $\mathbf{1}$ & $32-35$ & 10 \\
\hline $\mathbf{2}$ & $36-39$ & 8 \\
\hline $\mathbf{3}$ & $40-43$ & 10 \\
\hline $\mathbf{4}$ & $44-47$ & 8 \\
\hline $\mathbf{5}$ & $48-51$ & 9 \\
\hline $\mathbf{6}$ & $52-55$ & 16 \\
\hline $\mathbf{7}$ & $56-59$ & 11 \\
\hline $\mathbf{8}$ & $60-63$ & 17 \\
\hline $\mathbf{9}$ & $64-67$ & 18 \\
\hline $\mathbf{1 0}$ & $68-71$ & 34 \\
\hline $\mathbf{1 1}$ & $72-75$ & 15 \\
\hline $\mathbf{1 2}$ & $76-79$ & 12 \\
\hline $\mathbf{1 3}$ & $80-83$ & 15 \\
\hline $\mathbf{1 4}$ & $84-87$ & 19 \\
\hline $\mathbf{1 5}$ & $88-91$ & 6 \\
\hline $\mathbf{1 6}$ & $92-95$ & 7 \\
\hline $\mathbf{1 7}$ & $96-100$ & 11 \\
\hline & Total & 226 \\
\hline
\end{tabular}

Jumlah sampel dalam penelitian ini yaitu sebanyak 226 siswa dari 11 SD seKecamatan Prembun. Dari sampel tersebut diperoleh data hasil pengisian angket minat belajar dan hasil belajar matematika siswa yang telah didistribusikan ke dalam tabel distribusi hingga dapat diolah menggunakan perhitungan statistik dan kemudian dihitung nilai koefisien korelasi product moment ( $r$ ). Hasil uji normalitas sebaran terhadap variabel minat belajar menghasilkan nilai sig $=0,089$ ( $\mathrm{sig}>0,05)$ dan variabel hasil belajar matematika menghasilkan nilai sig $=0,061$ ( $\mathrm{sig}>0,05)$. Hasil uji 
berdasarkan kaidah menunjukkan variabel minat belajar dan hasil belajar matematika adalah normal. Hasil uji linieritas antara minat belajar dengan hasil belajar matematika memiliki sig $=0,936$ (sig $>0,05)$ yang berarti terdapat hubungan linier antara kedua variabel tersebut. Adapun hasil perhitungan korelasi dari data angket minat belajar dan tes hasil belajar matematika siswa kelas IV SDN yang telah diolah dapat dilihat pada tabel berikut.

Tabel 3. Hasil Analisis Korelasi Minat Belajar dengan Hasil Belajar Matematika

\begin{tabular}{llrr}
\hline \multicolumn{2}{c}{ Correlations } & \\
\hline & \multicolumn{1}{c}{ Minat Belajar } & $\begin{array}{r}\text { Hasil Belajar } \\
\text { Matematika }\end{array}$ \\
\hline Minat Belajar & $\begin{array}{l}\text { Pearson } \\
\text { Correlation }\end{array}$ & $.486^{* *}$ \\
\cline { 2 - 4 } & Sig. (1-tailed) & .000 \\
\cline { 2 - 4 } & $\mathrm{N}$ & 226 & 226 \\
\hline $\begin{array}{l}\text { Hasil Belajar } \\
\text { Matematika }\end{array}$ & $\begin{array}{l}\text { Pearson } \\
\text { Correlation }\end{array}$ & $.486^{* *}$ & 1 \\
\cline { 2 - 4 } & Sig. (1-tailed) & .000 & \\
\cline { 2 - 4 } & $\mathrm{N}$ & 226 & 226 \\
\hline${ }^{* *}$. Correlation is significant at the 0.01 level (1-tailed). & \\
\hline
\end{tabular}

Berdasarkan uji korelasi yang telah dilakukan menunjukkan bahwa nilai signifikansi (1-tailed) penelitian ini sebesar 0,000 < 0,05 yang berarti bahwa Ho ditolak, sehingga dapat ditarik kesimpulan bahwa ada korelasi positif antara minat belajar di sekolah dan hasil belajar matematika siswa kelas IV SDN se-Kecamatan Prembun. Hasil analisis koefisien korelasi antara variabel minat belajar dan hasil belajar matematika yaitu 0,486 yang berarti pada tingkat hubungan sedang. Berdasarkan pendapat Alaydrus dan Sarwono (2018: 102) tentang pedoman memberikan interpretasi koefisien korelasi versi de veus menyatakan bahwa koefisien korelasi pada 0,30-0,49 memiliki kekuatan hubungan moderat/sedang. Pada penelitian ini diperoleh nilai $r$ hitung $(0,486)>r$ tabel $(0,130)$ artinya terdapat hubungan positif dan signifikan antara minat belajar dengan hasil belajar matematika siswa kelas IV SDN seKecamatan Prembun.

Sesuai dengan hasil dari uji korelasi di atas, maka hipotesis yang menyatakan ada korelasi positif dan signifikan antara minat belajar dengan hasil belajar matematika siswa kelas IV SDN se-Kecamatan Prembun tahun ajaran 2020/2021 dapat diterima. Oleh karena itu dapat dikatakan bahwa semakin tinggi minat belajar siswa, maka akan semakin tinggi pula hasil belajar matematika yang diperoleh. Hal tersebut karena minat sebagai faktor internal siswa yang akan mempengaruhi hasil belajar. Untuk menunjukkan bahwa seorang siswa memiliki minat belajar dapat dilihat dari beberapa indikator yang meliputi perasaan senang, perasaan tertarik, pemusatan perhatian dalam belajar, partisipasi siswa, dan kemaun untuk belajar.

Perasaan senang yang dimiliki seorang siswa dapat membangkitkan semangat dalam belajar. Kegiatan yang diminati dan diperhatikan terus menerus dengan disertai rasa senang akan memberikan nilai dan hasil yang baik. Menurut Yamin (2018: 111) rasa senang memiliki pengaruh terhadap besarnya minat belajar siswa, karena bila dalam kegiatan pembelajaran siswa merasa tidak senang dan tidak berminat, siswa tidak akan belajar dengan sebaik-baiknya, karena tidak ada daya tarik baginya. 
Selain itu adanya perasaan tertarik merupakan awal dari individu menaruh minat, sehingga seseorang yang menaruh minat akan tertarik terlebih dahulu terhadap sesuatu (Charli, Ariani, dan Asmara, 2019: 55). Ketertarikan dalam minat belajar yang besar akan mendukung proses dan hasil belajar siswa dengan baik.

Dalam belajar diperlukan suatu pemusatan perhatian agar apa yang dipelajari dapat dipahami. Menurut Gazali dalam Slameto (2010) perhatian adalah keaktifan jiwa yang dipertinggi, jiwa itu pun semata-mata tertuju kepada suatu obyek (benda/ hal). Untuk dapat menjamin hasil belajar yang baik, maka siswa harus mempunyai perhatian terhadap bahan yang dipelajarinya, jika bahan pelajaran tidak menjadi perhatian siswa, maka timbulah kebosanan, sehingga siswa tidak lagi suka belajar. Aktivitas yang disertai dengan perhatian intensif akan lebih sukses dan prestasinya pun akan lebih tinggi (Charli, Ariani, dan Asmara, 2019: 55).

Timbulnya minat belajar pada individu juga didukung adanya partisipasi dalam belajar. Partisipasi merupakan keikutsertaan siswa dalam proses pembelajaran. Siswa yang mempunyai minat terhadap suatu pelajaran akan melibatkan dirinya dan berpartisipasi aktif dalam hal- hal yang berkaitan dengan kegiatan pembelajaran yang diminatinya. Partisipasi aktif siswa yang tinggi dalam pembelajaran akan menjadikan sebuah pembelajaran lebih efektif dan hasil belajar siswa yang baik (Nisa, 2017: 20).

Selain partisipasi, kemauan untuk belajar juga penting untuk menumbuhkan minat. Kuatnya kemauan siswa untuk belajar, akan mendukung pembelajaran berjalan dengan baik dan siswa dapat memperoleh hasil yang maksimal (Endriani, 2016: 111).

Apabila semua indikator tersebut dapat dilaksanakan secara optimal maka akan tercipta minat belajar yang baik. Minat belajar yang besar akan cenderung menghasilkan hasil belajar yang tinggi, sebaliknya jika minat belajar kurang maka akan menghasilkan belajar yang rendah (Suciyati dan Mariamah, 2018: 143).

Diterimanya hipotesis pada penelitian ini sesuai dengan penelitian yang dilakukan oleh Haryati (2015: 8) yang menyatakan bahwa terdapat hubungan antara minat belajar dengan prestasi belajar matematika siswa kelas $\mathrm{V}$ SDN gugus Wonokerto Turi Sleman dengan nilai korelasi positif yaitu 0,565 yang termasuk dalam kategori sedang. Hasil penelitian tersebut juga didukung oleh penelitian yang telah dilakukan oleh Rofiiqoh, Saptuti, dan Hidayah (2020: 483) yang menyatakan bahwa terdapat hubungan antara minat belajar dengan prestasi belajar matematika siswa kelas V SDN se-Kecamatan Kutoarjo dengan nilai korelasi positif yaitu 0,459 yang termasuk dalam kategori sedang.

Besarnya sumbangan efektif variabel minat belajar terhadap hasil belajar matematika pada penelitian ini yaitu sebesar $23,69 \%$ dan sisanya $76,31 \%$ dipengaruhi oleh faktor lain seperti bakat, inteligensi, kesehatan, perhatian, motivasi, kebiasaan belajar, lingkungan keluarga, lingkungan sekolah dan lingkungan masyarakat/ sekitar.

Berdasarkan uraian di atas, dapat diketahui bahwa semakin tinggi minat belajar, maka akan semakin tinggi pula hasil belajar matematika yang diperoleh siswa. Begitupun sebaliknya, semakin rendah minat belajar, maka akan semakin rendah pula hasil belajar matematika yang siswa peroleh. Oleh karena itu, dapat ditarik kesimpulan terdapat korelasi positif dan signifikan antara minat belajar dengan hasil belajar matematika siswa kelas IV SDN se-Kecamatan Prembun tahun ajaran 2020/ 2021.

\section{SIMPULAN}

Berdasarkan hasil penelitian dan pembahasan, dapat ditarik kesimpulan sebagai berikut:

1. Terdapat hubungan positif dan signifikan antara minat belajar dan hasil belajar matematika siswa kelas IV SDN se-Kecamatan Prembun dengan nilai $r$ hitung $(0,486)>r$ tabel $(0,130)$. 
2. Sumbangan variabel minat belajar terhadap hasil belajar matematika yaitu 23,69 $\%$ dan sisanya $76,31 \%$ dipengaruhi oleh faktor lain seperti bakat, inteligensi, kesehatan, perhatian, motivasi, kebiasaan belajar, lingkungan keluarga, lingkungan sekolah dan lingkungan masyarakat/ sekitar.

Menumbuhkan minat belajar pada siswa dapat dilakukan dengan berbagai cara seperti menciptakan kegiatan pembelajaran yang menarik, bervariatif dan menyenangkan, memberikan kesempatan yang sama kepada siswa untuk memecahkan masalah dan mengambil keputusan, menjalin hubungan yang baik antara guru, orang tua dengan siswa untuk menciptakan suasana yang nyaman dan aman bagi siswa dalam belajar, memberikan reward/hadiah, memberikan kesempatan kepada siswa untuk membentuk kelompok belajar, menciptakan kompetisi yang positif antar siswa, memberikan tanggung jawab kepada siswa, mendorong dan membimbing siswa untuk mengenal dan mengetahui minatnya, membimbing menemukan motivasi dari dalam dirinya, membantu memberikan jawaban dan menemukan solusi atas permasalahan yang dihadapi. Upaya menumbuhkan minat belajar siswa juga perlu didukung oleh pengoptimalan lingkungan belajar di sekolah dan peran orang tua.

\section{DAFTAR PUSTAKA}

Alaydrus, A.M., \& Sarwono. (2018). Analisis Faktor Keterlambatan Dimulainya Pelaksanaan Proyek Kontruksi pada Model Kontrak Rancang Bangun. Jurnal Konstruksia, 10 (1), 95-116.

Alwina, A., Syahrilfuddin, \& Fendrik, M. (2016). Hubungan Minat Belajar dengan Hasil Belajar Matematika Siswa Kelas V SDN Gugus 4 Kecamatan Limapuluh Kota Pekanbaru. Jurnal Online Mahasiswa, 3 (2): 1-12.

Anggriyani, K. (2020). Hubungan Minat dan Disiplin Belajar dengan Hasil Belajar Muatan IPS Siswa Kelas IV SDN Gugus Ahmad Yani Kabupaten Pekalongan. Skripsi. Semarang: Universitas Negeri Semarang.

Charli, L., Ariani, T., \& Asmara, L. (2019). Hubungan Minat Belajar terhadap Prestasi Belajar Fisika. SPEJ (Science and Physics Education Journal), 2 (2): 5260.

Endriani, A. (2016). Hubungan Perhatian Orang Tua dengan Motivasi Belajar pada Siswa Kelas VIII SMPN 6 Praya Timur Lombok Tengah Tahun Pelajaran 2015/2016. Jurnal Realita, 1 (2).

Flowerday, T \& Shell, D. (2015). Disentangling the effects of interest and choice on learning, engagement, and attitude. Journal Learning and Individual Differences, 40 (2015): $134-140$

Haryati, N. (2015). Hubungan Minat Belajar dengan Prestasi Belajar Matematika Siswa Kelas V SD Se-Gugus Wonokerto Turi Sleman Tahun Ajaran 2014/2015. Jurnal Pendidikan Guru Sekolah Dasar, 4(13).

Hewi, L., \& Shaleh, M. (2020). Refleksi Hasil PISA (The Programme For International Student Assesment): Upaya Perbaikan Bertumpu pada Pendidikan Anak Usia Dini). Jurnal Golden Age, 4 (1): 30-41. 
Nisa, K. (2017). Peningkatan Partisipasi Aktif dan Hasil Belajar Menggunakan Model Cooperative Learning Time Token pada Materi Ikatan Kimia Siswa Kelas X.1 SMA Negeri 8 Banjarmasin Tahun Pelajaran 2015/2016. Jurnal PTK dan Pendidikan, 3 (2): 19-26.

Nisa', R. (2018). Pengaruh Pola Asuh Orang Tua dan Interaksi Sosial terhadap Hasil Belajar Mata Pelajaran Matematika Siswa Kelas IV di Madrasah Ibtidiyah se-Kecamatan Lowokwaru Kota Malang. Tesis. Malang: Universitas Islam Negeri Maulana Malik Ibrahim.

Nugroho, A. S. (2020, 2 Mei). Strategi Belajar Kemendikbud di Masa Pandemi Covid-19. REPUBLIKA. Diperoleh 1 Maret 2021, dari https://www.republika.co.id/berita/q9oz63380/strategi-belajar-kemendikbud-dimasa-pandemi-covid-19

Priyatno, D. (2012). Belajar Cepat Olah Data Statistik dengan SPSS. Yogyakarta: Andi Yogyakarta.

Rofiiqoh, H., Saptuti, T., dan Hidayah, R. (2020). Hubungan Minat Belajar dan Hasil Belajar Matematika Siswa Kelas V SDN Se-Kecamatan Kutoarjo Tahun Ajaran 2019/2020. Jurnal IImiah Kependidikan, 8 (3): 480-484.

Siagian, M. D. (2016). Kemampuan Koneksi Matematik dalam Pembelajaran Matematika. MES (Journal of Mathematics Education and Science), 2 (1): 58-67.

Slameto. (2010). Belajar dan Faktor-faktor yang Mempengaruhinya. Jakarta: Rineka Cipta.

Suciyati \& Mariamah. (2018). Hubungan antara Minat Belajar dengan Hasil Belajar Matematika pada Siswa Kelas V SD Negeri 04 Sila. Jurnal Pendidikan MIPA, 8 (2): 142-149.

Sughiarti, S. (2016). Hubungan Minat Belajar dengan Hasil Belajar pada Siswa Kelas V Sekolah Dasar Gugus Wijaya Kusuma Ngaliyan semarang. Skripsi. Semarang: Universitas Negeri Semarang.

Susanto, A. (2016). Teori Belajar dan Pembelajaran di Sekolah Dasar. Jakarta: Kencana Prenadamedia Group.

Yamin, M. (2018). Penerapan Strategi Pembelajaran Active Knowledge Sharing untuk Meningkatkan Keterampilan Berkomunikasi dan Hasil Belajar IPA Siswa Kelas VIII SMP Negeri 2 Batukliang Tahun Pelajaran 2017/2018. Jurnal IImu Sosial dan Pendidikan, 2 (3). 